\title{
農薬の微生物代謝とその分解䤉素の進化的解析
}

\author{
田 村 勝 徳* \\ 東京大学分子細胞生物学研究所

\section{Microbial Pesticide Degradations and Evolutionary Analysis of Degrading Enzymes}

\author{
Katsunori TAMURA \\ Institute of Molecular and Cellular Biosciences, University of Tokyo, \\ 1-1-1, Yayoi, Bunkyo-ku, Tokyo 113-0032
}

\section{は じめに}

地球上に誕生した微生物は 30 数億年の間進化し続け, 天 然に存在する広範な芳香族化合物を基質として分解し利用 してきた。 その間に微生物間での遺伝子交換や代謝遺伝子 群の再編成などにより，代謝経路やその制御機構のレンジ を広げてきた.物質文明の基礎となった各種産業の発展は, こうした微生物を含む自然界の物質循環系にとって未経験 の新しい構造を持つ多くの化合物を産出してきた。特に， 農業の分野では夥しい数のハロゲン化有機化合物が人工的 に合成され，食料生産の安定確保のために直接的あるは間 接的に圃場に投与され続けている。それらの難分解性化合 物を利用し生育できる微生物は非常に限られており, 分解 能を示す微生物の単離および特徵付けや, 分解経路の起源 とその進化過程を解き明かすことは，難分解性化合物に対 する環境保全を目的とした微生物機能の開発といった観点 からも極めて重要かつ興味深い課題である。

ペンタクロロニトロベンゼン $(\mathrm{PCNB})$ は, 難防除病害で あるアブラナ科作物の根こぶ病などに卓効を示す土壌殺菌 剂としてかつて圑場に大量散布されていた，本薬剂は，物 理化学的に極めて安定で，一般に微生物分解に対しても耐 性であることから，土㙵中で長期間残留することが知られ ている ${ }^{1,2)}$.このため, ケミカルハザードとして固場を取り巻 く生態系へ何らかの影響を及ぼすことが懸念されていた。

一方，ホルモン系除草剂 2,4-ジクロロフェノキシ酢酸 (2,4-D) は広葉雑草の防除に広く用いられているが, それ

* $\overline{\mathbf{T}}$ 113-0032 東京都文京区弥生 1-1-1
らの畨場の土㙵中では速やかに代謝分解される．分解微生 物やその遺伝子に関してはこれまでに多くの研究報告があ るが，自然界に類縁化合物が存在しないこと，代謝酵素の 中で最初のステップを触媒する 2,4-D ジオキシゲナーゼは 唯一 2,4-D の代謝に特異的な酵素であること ${ }^{3)}$ から，本酵 素を含む分解経路の起源に関心がもたれた。

こうした背景から，本研究は 2 種類の芳香族塩化化合物 を例に取り，PCNB 剂の土堙中における微生物代謝機構の 解明および 2,4-D 分解経路の進化的な解析を行ったもので ある。

\section{PCNB 分解微生物の分布と特性}

PCNB は, 難防除病害であるアブラナ科作物の根こぶ 病，バレイショのそうか病，ナス，トマト，キュウリ，八 クサイ等の苗立枯病などの Rhizoctonia 属の病原菌に卓効 を示すこと文から，土㙵殺菌剂として毎年圃場に大量散布 されていた．本薬剤は，物理化学的に極めて安定で，一般 に微生物分解に対しても耐性であることから，多年に渡っ て固場に残留することが知られている ${ }^{1,2)}$ 。一方, 毎年繰り 返し散布されるために，分解微生物の集積等による根こぶ 病菌に対する殺菌力の低下が問題となっていた ${ }^{5)}$.また, 本 剂の残留物や代謝分解産物が畨場を取り巻く土堹環境等の 生態系に及ぼす影響が危惧されていた．PCNBの土壤中で の分解について, 微生物の関与が報告されているが1,2,6-8), それら分解能を持った微生物の単離や特徵付けに関する報 告はなされていなかった。そこで，広範な環境中から採集 した試料を用いて PCNB 分解活性を調查すると共に, 分解 微生物の分布と特性を検討した。 
Table 1 PCNB degrading activity of soil samples.

\begin{tabular}{lcc}
\hline Place & No. of samples $^{\text {a) }}$ & $\begin{array}{l}\text { No. of samples with } \\
\text { PCNB degradabilityb) }\end{array}$ \\
\hline Koumi Town* & 22 & $22(100)$ \\
Minakami Town & 4 & $3(75)$ \\
Wako City & 14 & $12(86)$ \\
Shinrin-Koen Area & 10 & $7(70)$ \\
Kamogawa City & 6 & $3(50)$ \\
Nasu-Kogen Area & 12 & $7(58)$ \\
Furano Town & 12 & $11(92)$ \\
Yakushima Area & 10 & $5(50)$ \\
Tsumagoi Village* & 24 & $22(92)$ \\
\hline Total & 114 & $92(81)$ \\
\hline
\end{tabular}

a) Samples were collected from diverse positions of each place. b) PCNB degradation means that more than $20 \%$ of PCNB was degraded.

* These places are cultivated fields where PCNB has been continually applied. All cultures were incubated under still conditions.

まず，PCNB 剂を毎年繰り返し散布している固場から土 壌を採集したほか, 山間地域, 海浜地域, 湖沼地域, 火山 帯地域などのPCNBに曝されていないと考えられる種々 の環境中から試料を採集し，それらの PCNB 分解能を試験 した．培地は $0.1 \% の$ 酵母エキスを含む最少塩培地を用い, PCNB を $20 \mu \mathrm{g} / \mathrm{ml}$ の濃度で添加した. $5 \mathrm{ml}$ の培地に約 $1 \mathrm{~g}$ の試料を加え, $28^{\circ} \mathrm{C} て ゙ 1$ 週間, 暗黒下で振とう条件または 静置条件で培養した後, 残留した PCNB および代謝産物を n一ヘキサンで抽出し, その一定量を用いてガスクロマトグ ラフィー/マススペクトロメトリー (GC/MS) により定量 分析した。その結果，PCNBの散布および污染の有無に関 わらず，供試した計 114 の試料中 92 の試料(約 80\%)で $20 \%$ 以上の PCNBの分解が認められた（Table 1).

次に, PCNBの分解活性が認められた試料から主として 細菌を単離し, さらに PCNB 分解能を検定したところ, 群 馬県水上町の山岳地带から採取した土堙から, 嫌気的条件 下で効率的に PCNBをPCA に変換する I-41株を選抜し た. I-41 株は静置培養条件下で $10 \mu \mathrm{g} / \mathrm{ml}$ の PCNB を 7 日 間でほぼ完全に分解したが，振とう条件下では 20\%以下の 分解に留まった，経時的には，本細菌の増殖は約 2 日間で 定常期に達し, その後 PCNB の代謝量は徐々に増加した。

7 日目には，添加したPCNBの約 70\%に対応する PCA が 検出された (Fig. 1). また, I-41 株は細菌学的諸性状を調査 したところ，Pseudomonas aeruginosa と同定された.

これらの結果から, PCNB を分解する微生物はPCNBの 散布の有無に関わらず広範な土堙中に生息しているものと 判断された。このことは, PCNB 分解菌の中でも強分解菌 として単離された I-41 株が山岳地帯からの土堙に由来す ること, 本細菌が様々な土壤や水圏環境等に幅広く存在す

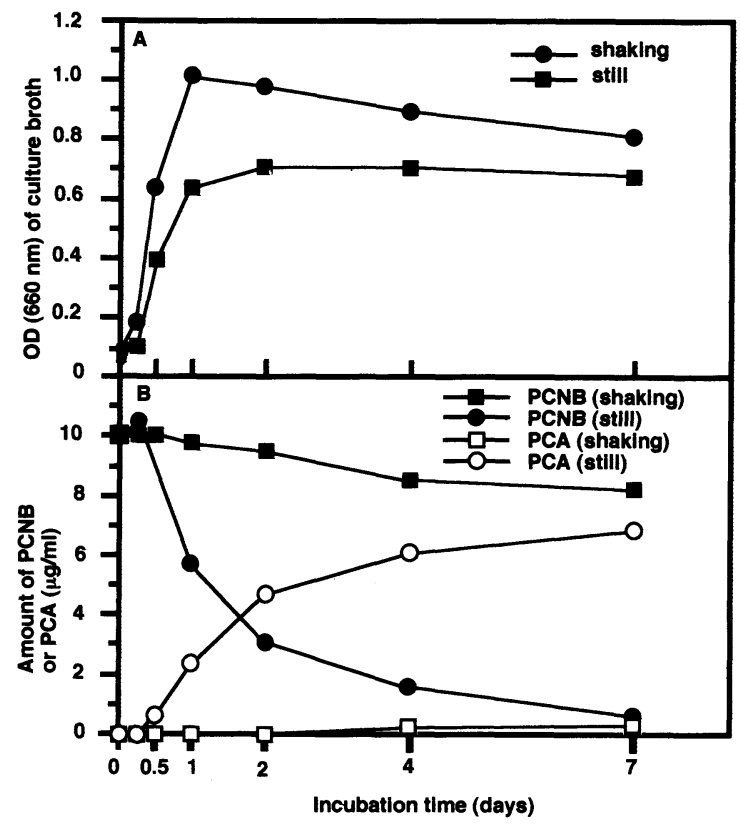

Fig. 1 Time course of bacterial population (A) and metabolism of PCNB to PCA by P. aeruginosa I-4l (B) under different culture conditions.

(A) The optical density $(660 \mathrm{~nm})$ of culture broth under shaking condition or still conditions. (B) Initial concentration of PCNB was $10 \mu \mathrm{g} / \mathrm{ml}$, and residual PCNB and produced PCA were extracted with $n$-hexane and analyzed by GC.

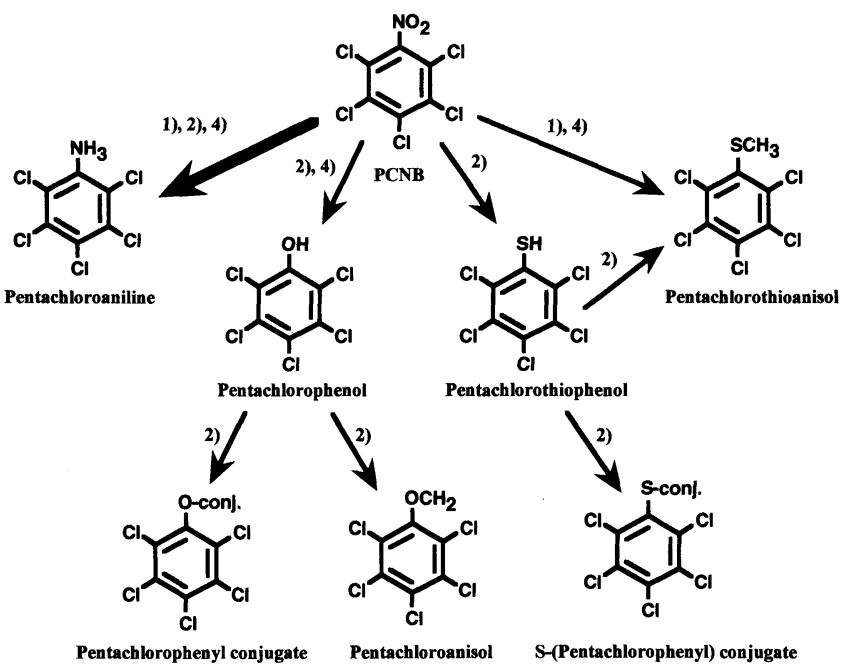

Fig. 2 Metabolic pathway of PCNB.

Each chemical is metabolized in 1) plant, 2) fish, 3) mammal, or 4) soil.

るP. aeruginosa $a^{9)}$ と同定されたことからも支持される.さ らに，1)PCNBの分解活性を示した殆どの土壤サンプルに おいて PCA が検出されたこと，2) I-41 株によるPCNBの 主要な代謝産物が PCA であったこと，3）著者らの予備実

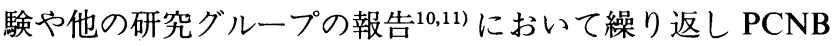
を散布した土壌における主要な残留物はPCA であったこ 
Table 2 Metabolism of PCNB and its related compounds by washed cells ${ }^{\text {a) }}$ of $P$. aeruginosa $\mathrm{I}-41$.

\begin{tabular}{lc}
\hline Compounds $(10 \mu \mathrm{g} / \mathrm{ml})$ & Rate of \\
\hline Pentachloronitrobenzene & 100 \\
2,3,5,6-Tetrachloronitrobenzene & 34 \\
2,4,5-Trichloronitrobenzene & 51 \\
Pentachloroaniline & 46 \\
Pentachlorothioanisole & 0 \\
Pentachlorophenol & 0 \\
Hexachlorobenzene & 0 \\
Tetrachloro-isophthalonitrile & 0 \\
\hline
\end{tabular}

a) Bacterial cells of isolate I-41 were grown for $24 \mathrm{hr}$ in MSY medium containing PCNB ( $1 \mu \mathrm{g} / \mathrm{ml})$, collected by centrifugation, washed twice with sterilized water and suspended in MSY medium $(O D 660=1.0)$, and PCNB or its related compounds were added $(10$ $\mu \mathrm{g} / \mathrm{ml})$. After 2 days incubation, each compound was analyzed.

とから, 土壌環境中における PCNBの主要な微生物代謝経 路はPCAへの還元的変換であると結論付けられた

(Fig. 2).

また，I-41 株はPCNB の他，2,3,5,6-テトラクロロニトロ

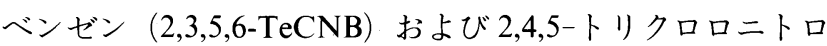

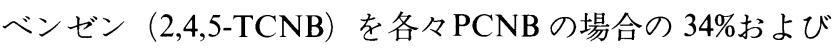
$51 \% の$ 効率で代謝し，主な代謝産物として各々 2,3,5,6-テト ラクロロアニリン (2,3,5,6-TeCA) および 2,4,5-トリクロロ アニリン (2,4,5-TCA) を生じたのに加え，PCA を46\%の効 率で代謝した。これに対して，関連化合物であるペンタク ロロチオアニソール (PCTA), ペンタクロロフェノール $(\mathrm{PCP})$, ヘキサクロロベンゼン (HCB) およU゙テトラクロ ロイソフタロニトリル（TPN）を全く代謝しなかった (Table 2).

I-41 株から無細胞抽出液を調製し, PCNBから PCA へ の変換が還元酵素反応によることを確認した．過去のニト

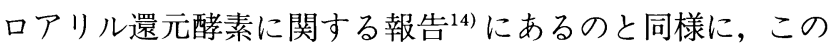
PCNB を還元代謝する酵素はニトロアリル化合物に対し てさほど高い基質特異性を持なないと考えられた。した がって，I-41 株による PCNBの還元反応はこの化合物に特 異的であるわけではなくむしろ付随的な反応であるものと 推察された.さらに, PCNBの PCA への変換は, 糸状菌6,10) や植物 ${ }^{11,15-15)}$, 動物 ${ }^{18,19)}$ においても観察されており, 生物学 的に非特異的な反応であると考えられた ${ }^{12)}$.

土壤微生物の増殖に及ぼす PCNB および PCA の影響を 調べるために，I-41 株を用いて，培地に添加する PCNB の 濃度が I-41 株の生育またはPCNBの代謝に及ぼす効果お よび各種濃度の PCA が I-41 株の生育に及ぼす効果を検討 した。その結果, 培地に添加した $200 \mu \mathrm{g} / \mathrm{ml}$ 以上の PCNB は I-41 株によるPCNBの代謝そのものは阻害しないが, $\mathrm{I}-41$ 株の増殖を著しく抑制することが明らかとなった (Fig. 3).また, $200 \mu \mathrm{g} / \mathrm{ml}$ 以上の PCA によって I-41 株の

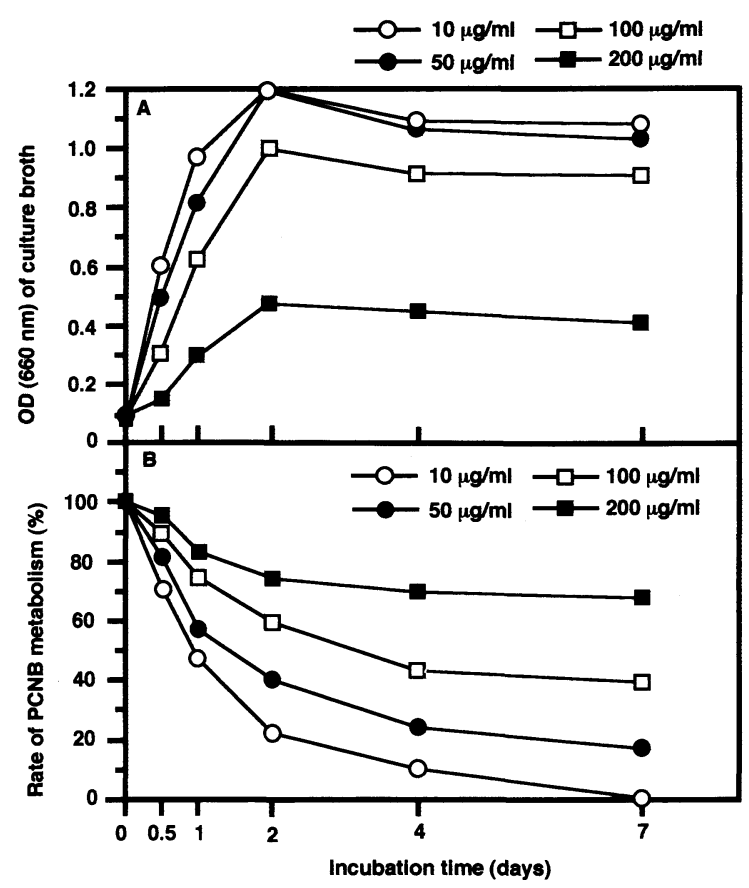

Fig. 3 Effect of PCNB concentrations on growth rate (A) and PCNB metabolism (B) by $P$. aeruginosa I-41.

(A) The optical density $(660 \mathrm{~nm})$ of culture broth under still conditions. Initial concentrations of PCNB are indicated.

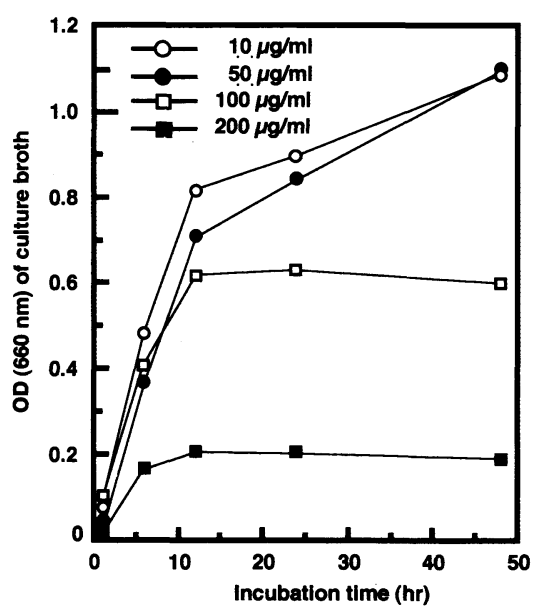

Fig. 4 Effect of PCA concentrations on growth rate of $P$. aeruginosa $\mathrm{I}-41$.

The optical density $(660 \mathrm{~nm})$ of culture broth under still conditions. Initial concentrations of PCNB are indicated.

生育は著しく抑制された(Fig. 4).PCA による I-41 株の生 育阻害効果の機構は不明であるが，Ko \& Farly'1) は様々な 微生物に対して PCA は生育阻害活性を持つことを報告し ており, Marthy \& Kaufman ${ }^{10)}$ は嫌気的条件で PCA は土壤 中の呼吸作用を強く阻害することを示している.これらの 事実から，毎年大量に土壌散布されている圃場では，高濃 度の PCNB やその代謝産物である PCA の蓄積が，本来の 
防除対照である植物病原菌以外に土壌に生息する微生物の 群集密度に何らかの影響を与える可能性が考えられ $た^{12,13)}$.

一方，PCNB 剂を毎年繰り返し散布している長野県の キャベッ栽培戋場由来の土壌試料から，好気的条件下で PCNB を代謝するPseudomonas 属細菌 N9002 株を単離し た。本菌は振とう培養条件で $20 \mu \mathrm{g} / \mathrm{ml}$ の PCNB を7 日間 で $80 \%$ 以上分解したが, 培養液中に PCA の蓄積や予想さ れる代謝産物である PCTA および PCP は検出されなかっ た。また，本菌はPCNBの他，PCA およびPCTA を分解 したが, PCPの分解能は認められなかった。本菌から調製 した無細胞抽出液はPCNB, PCA およびPCTA を代謝し たことから，代謝経路に必要な複数の酵素が含まれている ことが確認された. N9002 株による PCNBの分解経路に脱 塩素反応が含まれるかどうかを検討するために，水銀チオ シアネート発色法により培養液中に遊離した塩素イオンの 検出を行ったところ, 経時的な PCNBの減少に伴って遊離 した塩素イオン量の増加が認められた (Fig. 5). 以上の結果 から, N9002 株が新規の PCNB 代謝経路を有する可能性が

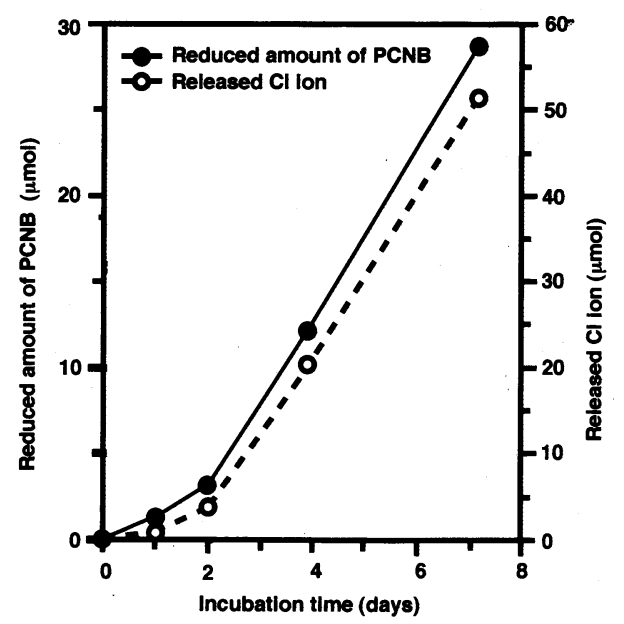

Fig. 5 Degradation of PCNB and release of chloric ion by Pseudomonas sp. N9002.

Initial concentration of PCNB was $50 \mu \mathrm{mol}$, and residual PCNB was extracted with $n$-hexane and analyzed by GC. The amount of chloric ion in the culture medium at each incubation time was measured by using a mercuric thiocyanate colorimetric method.
示唆され，その詳細な解明が今後期待される.

\section{2,4-D 分解経路の進化的解析}

2,4-D はホルモン系合成除草剂で，主に広葉雑草を防除 するために世界的に広く用いられている。本剤は土壌中で 速やかに分解されるが，そのような土堙からはこれまでに 多くの 2,4-D 分解菌が単離され, それらの系統的分類, 代謝 遺伝子群の解析や土㙋中での個体群動態などの研究が行わ れてきた ${ }^{20-25)}$. 中でも, Ralstonia eutropha JMP134 株は 2,4-D 分解菌研究のモデルとして最も研究の進んだ細菌の 一つで, 2,4-D 分解に必要な代謝遺伝子群 $(t f d A \sim t f d F)$ お よび制御遺伝子 $(t f d S, t f d R)$ を伝達性プラスミド $\mathrm{pJP} 4$ 上 に有することが知られている ${ }^{26-30)}$. さらに, このような伝達 性プラスミドが 2,4-D 分解遺伝子の水平伝播に関与するこ とが示されている31.

2,4-D 代謝の最初のステップを担う $t f d A$ 遺伝子は, 2,4-D から 2,4-ジクロロフェノールへの変換を触媒するジオキシ ゲナーゼをコードする遺伝子で ${ }^{32,33)}$ ，その後の代謝経路を 担う他の $t f d$ 遺伝子群とは異なり, 進化的に関連のある遺 伝子が他の代謝系からは見い出されていない. また, 2,4-D が世に生まれて半世紀余であるが，現在までのところ自然 界には 2,4-D に類縁な化合物の存在は知られていない。こ うした背景から，2,4-D 分解菌が如何にして代謝経路を獲 得してきたかを知ることはとりわけ興味深い. そこで2,4$\mathrm{D}$ 分解遺伝子の起源を探る目的で，かつて 2,4-D に全く曝 されていないと考えられる原始土壌を試料に用いて2,4-D 分解菌の探索を行い, 分離された菌の性状を生理学的およ び遺伝学的に調查するとともに，2,4-D 代謝遺伝子の伝達 性について検討した。

世界各地から採集された天然土㙵の中から注意深く 30 試料を選び, まず 2,4-D 分解活性を調査した.そのうち 7 試 料に分解活性が認められ，その中で最も強い活性を示した ハワイ火山性土壤から分解菌を単離することにした。 土堙 試料を2,4-D を含む培地で 10 回以上集積培養した後, 2,4-D の分解に伴う $\mathrm{pH}$ 指示薬の変色あるいは ${ }^{14} \mathrm{C}-2,4-\mathrm{D}$ の取り込みを指標にして分解菌を単離した。採取場所の異 なる 3 つの試料からは REP-PCR 法により各々遺伝的背景 が異なることが判明した 3 種類の細菌（HW1，HWK12，

Table 3 2,4-D degrading isolates from Hawaiian pristine soil.

\begin{tabular}{|c|c|c|c|c|c|}
\hline Strain & Origin & Morphology & $\begin{array}{l}\text { REP-PCR* } \\
\text { Type }\end{array}$ & $t f d A$ & $\begin{array}{l}\text { Phylogenetic position } \\
\text { based on 16S rDNA }\end{array}$ \\
\hline $\begin{array}{l}\text { HW1 } \\
\text { HW13 } \\
\text { HWK12 }\end{array}$ & $\begin{array}{l}\text { HW1 } \\
\text { HW13 } \\
\text { HWK12 }\end{array}$ & $\begin{array}{l}\text { Short rod } \\
\text { Long bent rod } \\
\text { Long bent rod }\end{array}$ & $\begin{array}{l}\text { I } \\
\text { II } \\
\text { III }\end{array}$ & $\begin{array}{l}\text { YES } \\
\text { NO } \\
\text { NO }\end{array}$ & $\begin{array}{l}\text { Variovorax } \\
\text { Bradyrhizobium or Nitrobacter } \\
\text { Bradyrhizobium or Nitrobacter }\end{array}$ \\
\hline
\end{tabular}

*REP-PCR: Repetitive Extragenic Palindromic Polymerase Chain Reaction 
HW13）が分離された ${ }^{3)}$ (Table 3). 菌の形態は HW1 株が 短桿状, HWK 12 株および HW13 株が湾曲した桿状で, tfdA に特異的なプライマーを用いた PCR では HW1 株か らのみ期待された約 $300 \mathrm{bp} の$ 断片が増幅された 㙵試料を用いた同様の PCR では HW1 株が分離された土 壤からのみ增幅断片が検出されたことから, 土壤を採取し た当初から試料中に $t f d A$ 遺伝子が存在していたことを確 認している.これら 3 種細菌はリボゾーム RNAの部分塩 基配列に基づいて, 各々 HW1 株が Variovorax 属, HWK12 株およびHW13株がBradyrhizobium属あるいは Nitrobacter 属菌に分類された. さらに, HW1 株から増幅さ れた約 $300 \mathrm{bp}$ の遺伝子断片の塩基配列は $\mathrm{pJP} 4$ 由来の tfdAのそれに対して 98\%の相同性を示したことから，両者 がほぼ同一の遺伝子であることが判明した3゙.

次に, HW1 株を用いてさらに 2,4-D 代謝遺伝子の解析を 行った。まず, $\mathrm{pJP} 4$ 由来の $t f d A \sim t f d C$ の遺伝子プローブ を用いてサザン解析を行ったところ, HW1 株から抽出し たDNA は $t f d A$ とは八イブリッドを形成したが, その後の 代謝経路を担う $t f d B$ および $t f d C$ とは八イブリッドを形 成しなかった. HWl 株から tfdA を含む $3.0 \mathrm{~kb}$ の SmaI 断 片を広宿主域プラスミドベクターにクローン化した後, $R$. eutropha JMP228（pBH501aE）株内で発現させ, 2,4-Dの 分解能を確認した。なお, JMP228 株は pJP4 を除去した JMP134株のリファンピシン耐性変異株で, プラスミド $\mathrm{pBH} 501 \mathrm{aE}$ は $\mathrm{pJP} 4$ の $t f d A$ 遺伝子領域を部分的にカナマイ シン耐性遺伝子 (nptII) カセットで置換することにより $t f d A$ を不活化した変異体である ${ }^{34)}$. また, HW1 株が持つ $t f d A$ 遺伝子が他の細菌に転移し得るかどうかを明らかに するため，JMP228 株またはJMP228（pBH501aE）株を受 容菌として用いてプレート交配法により接合実験を行っ た. 各々の受容菌については, JM228 株は一連の tfd 遺伝子 群を相補するかどうか, JMP228 (pBH501aE) 株は tfdA 遺 伝子のみを相補するかどうかを同時に検討するために供試 したものである。その結果, 後者を受容菌に用いた場合に のみ, $1 \mathrm{mM}$ の 2,4-D およびリファンピシンを含む無機塩 培地上で $5 \times 10^{-7}$, カナマイシンを添加した同培地上では $4 \times 10^{-8}$ の頻度で $2,4-\mathrm{D}$ 分解能を獲得した接合体が得られ た。この結果から, HW1 株の $t f d A$ 遺伝子が伝達性のプラ スミドなどを介した接合伝達により JMP228 (pBH501aE) 株へ転移したものと考えられた。そこで, 常法により HW1 株からプラスミドの検出を試みたが確認できなかったた め, パルスフィールドゲル電気泳動を行ったところ, 約 620

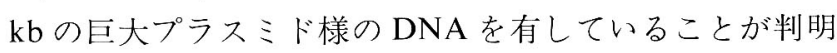
した.このプラスミド様 DNA は pJP4の tfdAプローブと ハイブリッドを形成したが, $t f d B$ 抢よび $t f d C$ プローブと はハイブリッドを形成しなかったことから，HW1株は $t f d A$ 遺伝子のみをプラスミド上に保有していることが明

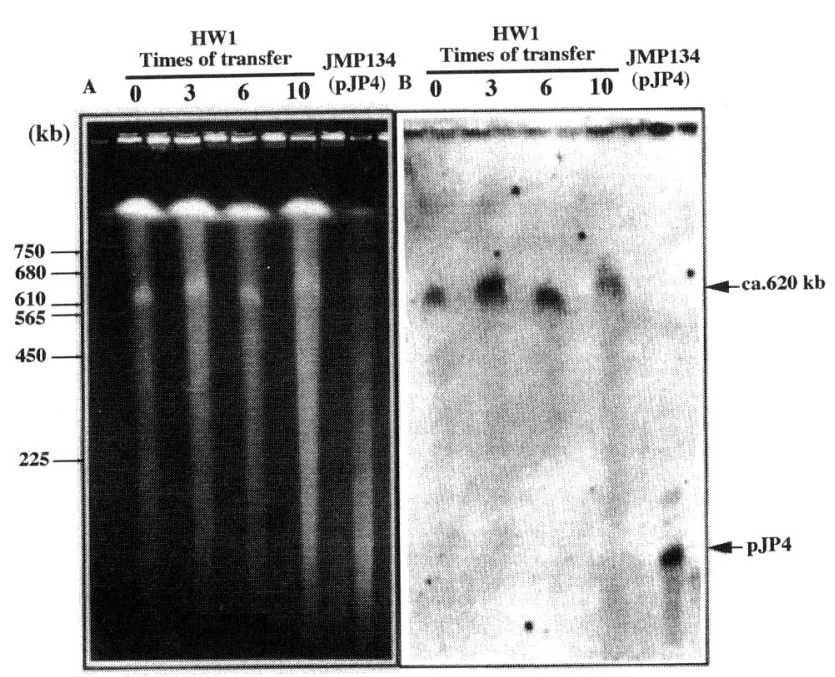

Fig. 6 (A) Detection of plasmid DNA from Variovorax $\mathrm{sp.}$ HW1 by pulsed field gel electrophoresis (PFGE) and (B) hybridization with $t f d A$ probe.

A, The numbers of left side indicate the sizes of Sccharomyces cerevisiae DNA used as the molecular standard marker. HWl culture was transferred for each indicated time, and was subjected to be analyzed by PFGE. The range of DNA separation was $100 \mathrm{~kb}-1.2 \mathrm{Mb}$. Hybridization was carried out under high stringency conditions.

らかになった(Fig. 6)。さらに，2,4-D 分解能を獲得した接 合体を用いたサザン解析から，HW1 株の巨大プラスミド は接合体内で維持されておらず, tfdA は $\mathrm{pBH} 501 \mathrm{aE}$ 上に位 置していることが明らかとなった。またここれらのことを 実証するために，HW1 株からクローン化した tfd $A$ を含む プラスミド $\mathrm{pBSH}$ をエレクトロポーレーション法で JMP228 株 (pBH501aE) に導入することによっても，2,4-D 代謝能を持つ形質転換体が得られた。これら接合体掞よび 形質転換体は $t f d A$ を $\mathrm{pJP} 4$ のそれと全く同位置に持つこ とが確認された. HW1 株の $t f d A$ 遺伝子 ORFの上流と下 流領域の塩基配列は $\mathrm{pJP} 4$ に扔けるそれらに対して 90\%以 上の相同性を示したことから，tfdA が相同組換えにより $\mathrm{pBH} 501 \mathrm{aE}$ の ntII カセットと置換したものと考えられ た。一方，nptII をプローブとしたサザン解析は，これら接 合株㧍よび形質転換株はいずれも $\mathrm{pBH} 501 \mathrm{aE}$ と同位置に nptII を持つプラスミドを同時に保有していることを示し た. 以上より, HW1 株の遺伝子伝達には巨大プラスミドの 接合伝達および引き続き起こる HWI 株の $t f d A$ 遺伝子近 傍の配列と pBH501aE 中の配列の間での相同的組み換え が関与していることが示唆された。

かつて2,4-Dに曝されたことのないと考えられるハワイ 火山性土壌から分離された HW1 株が, 如何なる目的で 2,4-D 分解遺伝子である tfdA を有していたかは現在のと ころ全く不明であるが，2,4-D が使用される以前からその 分解遺伝子が既に自然界に存在していたことは確かであろ 
j.さらに, 原始土壌に生息する細菌が持つ $t f d A$ が他の菌 に伝達され得るという事実は, HW1 株のような細菌の 2,4$\mathrm{D}$ 代謝遺伝子が現在围場等に広く拡散し，これまでに多数 分離されている2,4-D 分解菌のそれの起源である可能性を 強く示唆するものと考之られる ${ }^{3}$.

\section{おわりに}

実際に，固場に散布された薬剤が土壌中で如何なる運命 を辿るのか, あるいは残留農薬が土壌微生物の群集密度に どのような影響を及ぼすかを正確に把握するためには，围 場レベルでの緻密な実験検討が必要であるが, 本研究で得 られた結果は, 今後少なくとも PCNB 用の土壤微生物によ る代謝分解の全容解明を進める上で重要な指針を与えるも のと考えられる。これまでの過去の研究成果により，2,4-D 分解微生物やそれらの代謝遺伝子に関して体系的な理解が 可能になった観があるが，2,4-D に曝された歷史を持たな い原始土壌にその分解菌および代謝遺伝子の起源を求める という本研究での新たな切り口により, 微生物進化の足跡 を垣間見る機会が得られたものと思われる。これら PCNB の微生物分解機構に対寸る理解や，2,4-D 代謝経路の起源 や伝搬性に関する知見は，微生物等の働きを利用して難分 解性化学物質を分解处理するバイオリメディエーション技 術の応用開発に向けた学術的基盤の整備に少なからず資す るものと期待される.

本研究を遂行するにあたり, 理化学研究所主任研究員 山口勇 先生には, 農薬の分解微生物などに関する貴重なご指導, ご鞭撻 を賜りました。 また，同主任研究員 工藤俊章先生，東京工業大 学名誉教授 堀越弘毅先生, 長岡技術科学大学教授 福田雅夫先 生, 同教授 故矢野圭二先生, ミシガン州立大学教授 J. M. Tiedje 先生, 同助教授 L. J. Forney 先生には, 微生物学などに関する 様々なご指導, ご教示を賜りました. 東心より深く感謝申し上げ ます。旧通産省工業技術院主任研究員 鎌形洋一先生, 海洋科学 センター主任研究員 高見英人先生, 現明治大学講師 前田理久 先生, 現パーデュー大学助教授 C. Nakatsu 先生, 現トロント大 学助教授 R. A. Fulthorpe 先生には共同研究を通して様々なご 教示を頂きました. 理化学研究所微生物制御研究室研究員 長谷 川志氏には実際の研究に携わって頂きました。 その他にも様々 な方々から,ご援助ならびにご協力をして頂きました. 厚く御礼 申し上げます。

本研究は，旧科学技術庁新技術事業団微生物進化プロジェク トチームおよびミシガン州立大学微生物生態センターの共同研 究プロジェクトとして行われたものです。ここに記して樑謝の 意を表します。

\section{引用 文 献}

1) W. H. Ko \& J. D. Farley: Phytopathology 59, 64 (1969)

2) T. Nakanishi: Ann. Phytopathol. Soc. Jpn. 38, 249 (1972)

3) Y. Kamagata, R. R. Fulthorpe, K. Tamura, H. Takami, L. J. Forney \& J. M. Tiedje: Appl. Environ. Microbiol. 63, 2266 (1997)

4) T. Nakanishi \& H. Oku: Ann. Phytopathol. Soc. Jpn. 36, 67 (1970)
5) K. Suyama \& H. Okazaki: Abstr.; 19th Annual Meeting of Pestic. Sci. Soc. Jpn. D111, 1994 (in Japanese)

6) C. I. Chacko, J. L. Lockwood \& M. Zabik: Science 154, 893 (1966)

7) T. Nakanishi \& H. Oku: Ann. Phytopathol. Soc. Jpn. 35, 339 (1969)

8) T. Nakanishi \& H. Oku: Phytopathology 59, 1761(1969)

9) N. R. Krieg \& J. G. Holt: "Bergey's Manual of Systematic Bacteriology," Vol. 1, 8th Ed., The Williams \&Wilkins Company, London, p. 164, 1984

10) N. B. Murthy \& D. D. Kaufman: J. Agric. Food Chem. 26, $1151(1978)$

11) M. Ogiso \& H. Tanabe: J. Pesticide Sci. 7, 391 (1982)

12) K. Tamura, Y. Hasegawa, T. Kudo \& I. Yamaguchi: $J$. Pesticide Sci. 20, 145 (1995)

13) K. Tamura, Y. Hasegawa, T. Kudo \& I. Yamaguchi: "Microbial Diversity and Genetics of Biodegradation," $\mathrm{K}$. Horikoshi et al. Ed., Japan Scientific Societies Press, Tokyo, p.113, 1997

14) I. Yamashita: Biochem. J. 27, 85 (1954)

15) S. Gorbach \& U. Wagner: J. Agric. Food Chem. 15, 654 (1967)

16) G. L. Lamoureux, J.-M. Gouot, D. G. Davis \& D. G. Rusness: J. Agric. Food Chem. 29, 996 (1981)

17) D. G. Rusness \& G. L. Lamoureux: J. Agric. Food Chem. 28, 1070(1980)

18) P. W. Aschbacher \& V. J. Feil: J. Agric. Food Chem. 31, 1150 (1983)

19) E. J. Kuchar, F. O. Geenty, W. P. Griffith \& R. J. Thomas: J. Agric. Food Chem. 17, 1237 (1969)

20) M. A. Bhat, M. Tsuda, K. Horiieke, M. Nozaki, C. S. Vaidyanathan \& T. Nakazawa: Appl. Environ. Microbiol. 60, 307 (1994)

21) G. R. Chaudry \& G. H. Huang: J. Bacteriol. 170, 3897 (1988)

22) J. O. Ka \& J. M. Tiedje: J. Bacteriol. 145, 1365 (1994)

23) J. O. Ka, W. E. Holben \& J. M. Tiedje: Appl. Environ. Microbiol. 60, 1106 (1994)

24) J. O. Ka, W. E. Holben \& J. M. Tiedje: Appl. Environ. Microbiol. 60, 1121 (1994)

25) A. A. Maë, R. O. Marits, N. R. Ausmees, V. M. Kôiv \& A. L. Heinaru: J. Gen. Microbiol. 139, 3165 (1993)

26) P. S. Amy, J. W. Schulke, L. M. Frazier \& R. J. Seidler: Appl. Environ. Microbiol. 49, 1237 (1985)

27) R. H. Don \& J. M. Pemberton: J. Bacteriol. 161, 466 (1985)

28) R. H. Don, A. J. Weightman, H.-J. Knackmuss \& K. N. Timmis: J. Bacteriol. 145, 681 (1985)

29) B. Kaphammer \& R. H. Olsen: J. Bacteriol. 172, 5856 (1990).

30) B. Kaphammer B., J. J. Kukor \& R. H. Olsen: J. Bacteriol. 172, 2280 (1990)

31) R. H. Don \& J. M. Pemberton: J. Bacteriol. 145, 681 (1981)

32) F. Fukumori \& R. P. Hausinger: J. Bacteriol. 175, 2083 (1993)

33) F. Fukumori \& R. P. Hausinger: J. Biol. Chem. 268, 24311 (1993)

34) W. E. Holben, B. M. Schroeter, V. G. Calabrese, R. H. Olsen, J. K. Kukor, V. O. Biederbeck, A. E. Smith \& J. M. Tiedje: Appl. Environ. Microbiol. 58, 3941 (1992) 


\section{Microbial Pesticide Degradations and Evolutionary Analysis of Degrading Enzymes}

\section{Introduction}

Although the major metabolic pathways of microorganisms evolved millions of years ago, molecular evolution has not ceased. Developments in the chemical industries over the past several decades have resulted in the synthesis of numerous artificial compounds and their release into the natural environment. In agriculture, for example, halogenated organic compounds have been applied in abundance to cultivated land as pesticides in order to obtain stability in crop yields. The introduction of xenobiotic chemicals to nature has created opportunities for the evolution of metabolic pathways that allow microorganisms either to exploit new carbon sources or to detoxify harmful compounds.

The pesticide pentachloronitrobenzene (PCNB) has been widely used as a fungicide, especially for the control of clubroot disease of cruciferous vegetables. This compound is physicochemically stable and generally resistant to microbial degradation, and it is thought to remain in soil for many years after its application. Given that large quantities of this fungicide have been repeatedly applied to cultivated fields during the last few decades, residual PCNB or its metabolites may affect nontarget soil microorganisms and result in ecological hazards. In addition, the synthetic herbicide 2,4dichlorophenoxyacetic acid (2,4-D) has also been applied to crops over the past 5 decades for the control of broad-leaf weeds. Several microorganisms that are able to degrade 2,4-D have been isolated from soil with a history of exposure to this herbicide, and the catabolic genes of these isolates have been extensively investigated. Among the genes that contribute to 2,4-D catabolism, tfd $A$, which encodes an enzyme responsible for the first step of this process, is relatively specific to the 2,4-D degradation pathway. Given that no naturally occurring analogs of 2,4-D are known, it is of interest to determine the mechanism by which the ability to degrade 2,4-D developed in soil microorganisms.

In this study, the microbial degradation of PCNB in soil environments and the molecular evolution of the 2,4-D metabolic pathway were examined.

\section{Distribution and Characterization of PCNB-degrading Microorganisms}

Although several studies of the degradation of PCNB in soil have implicated soil microorganisms in this process, few such studies have described the characteristics of the PCNB-degrading microbes. We therefore screened for the presence of PCNB degraders in soil samples that were collected not only from cultivated fields exposed to PCNB but also from noncultivated areas including mountainous terrain, volcanic zones, and beach regions as well as industrial activated sludge. Each soil sample $(1 \mathrm{~g})$ was placed in $5 \mathrm{ml}$ of mineral salt medium containing $0.1 \%$ yeast extract and PCNB $(20 \mu \mathrm{g} / \mathrm{ml})$, and was incubated for 7 days at $28^{\circ} \mathrm{C}$ with or without shaking. Under nonagitated conditions, 92 out of a total of 114 samples mediated an extent of PCNB degradation of $>$ $20 \%$, suggesting that PCNB-degrading microorganisms were present in most of the soil environments irrespective of the previous application of PCNB. From a soil sample with a high PCNB degradation rate, a bacterial strain (I-41) was isolated as the most efficient degrader of PCNB and identified as Pseudomonas aeruginosa. Incubation of I-41 under nonagitated conditions with PCNB at a concentration of $10 \mu \mathrm{g} / \mathrm{ml}$ resulted in the degradation of almost all of the pesticide within 1 week; in contrast, only $18 \%$ of the PCNB was degraded under shaking conditions. Characterization of the time course of PCNB degradation by this bacterium revealed that bacterial growth achieved stationary phase within 2 days and that the breakdown of PCNB correlated with the increase in the bacterial population. In addition, pentachloroaniline (PCA) was detected in most soil samples that mediated PCNB degradation, and the principal metabolite of PCNB in I-41 was confirmed to be PCA. Together with previous observations indicating that PCA is the major metabolite of PCNB in soil samples from fields repeatedly subjected to PCNB application, our results suggest that the main pathway for PCNB degradation in soil environments is the reductive conversion of PCNB to PCA.

I-41 mediated the reduction not only of PCNB to PCA but also of tetrachloronitrobenzen (TeCNB) to tetrachloroaniline (TeCA) and of trichloronitrobenzen (TCNB) to trichloroaniline (TCA). The observation that a cell- 
free extract of I-41 also mediated the reductive degradation of PCNB demonstrated that this process is the result of an enzyme-catalyzed reaction. The enzyme system responsible for the reduction of PCNB thus appears to possess a relatively low substrate specificity among nitroaryl compounds. Indeed, nitroaryl reductase systems have been shown to exhibit low substrate specificity. The reduction of PCNB by I-41 might thus be an incidental property of this bacterium rather than reflect the existence of a dedicated PCNB degradation pathway. Moreover, the degradation of PCNB to PCA has been observed in some fungi, plants, and animals, suggesting that catalysis of this reaction is a nonspecific biological property.

PCNB is a potent fungicide and is especially effective against Plasmodiophora brassicae and Rhizoctonia solani. However,PCNBatconcentrations of $>200 \mu \mathrm{g} / \mathrm{ml}$ also markedly inhibited the growth of I-41, as did PCA at $200 \mu \mathrm{g} / \mathrm{ml}$. These observations suggest that high concentrations of PCNB or PCA might affect the population of soil microorganisms in addition to the target plant pathogens in fields repeatedly exposed to PCNB in large amounts.

Another PCNB-degrading bacterium, designated Pseudomonas sp. N9002, was isolated from a cabbage field in which PCNB had been applied annually for at least 5 years. This organism mediated the degradation of virtually all of the fungicide within 1 week when incubated under shaking conditions with PCNB at a concentration of $20 \mu \mathrm{g} / \mathrm{ml}$. Neither PCA, pentachlorothioanisol (PCTA), nor pentachlorophenol (PCP) was detected during the degradation of PCNB by N9002, whereas the release of free chlorine ions was observed with the use of the colorimetric mercury thiocyanate method. These results suggest that N9002 degrades PCNB through an unknown mechanism that includes dechlorination.

\section{Molecular Evolution of a 2,4-D Metabolic Pathway}

Several microorganisms able to degrade 2,4-D have been isolated to date from soils with a history of exposure to this herbicide, and their catabolic genes have been extensively investigated. Ralstonia eutropha JMP134 is one of the best characterized 2,4-D degraders and has been shown to harbor a plasmid, pJP4, on which the catabolic genes ( $t f d A$ through $t f d F$ ) and corresponding regulatory genes ( $t f d R$ and $t f d S$ ) responsible for 2,4-D degradation are located. The tfdA gene encodes $\alpha$ ketoglutarate-dependent 2,4-D dioxygenase ( $\operatorname{TfdA})$, which catalyzes the first step of 2,4-D metabolism. Unlike the other $t f d$ catabolic genes, $t f d A$ is relatively specific to 2,4-D degradation, and other sequences evolutionarily related to $t f d A$ have not been detected. Therefore, little is known of the origin and essential function of $t f d A$ in natural environments.

Recently, 2,4-D-degrading activity has been detected in the soil of several pristine ecosystems that had not been exposed to 2,4-D or to other halogenated organic compounds. With the use of 2,4-D dye indicator medium or ${ }^{14} \mathrm{C}$-labeled 2,4-D medium, a previously unidentified group of oligotrophic bacteria capable of degrading 2,4-D was thus isolated from enrichment cultures of volcanic soil derived from geographically remote regions of Hawaii. Phylogenetic analysis based on 16S rDNA sequencing and characterization of the physiological properties of these bacteria revealed that isolate HW1 belongs to the genus Variovorax and that isolates HWK 12 and HW13 possess 16S rDNA sequences that exhibit a high degree of similarity to those of Bradyrhizobium species. All of the isolates grew slowly on 2,4-D medium, with mean generation times of 16 to $30 \mathrm{hr}$, which are substantially longer than those of previously identified 2,4-D degraders. Polymerase chain reactionmediated amplification and Southern hybridization analysis revealed that $\mathrm{HW} 1$ harbors a $t f d A$ gene almost identical to that of pJP4 but does not possess genes homologous to $t f d B$ or to $t f d C$. Cloning of a $3.0-\mathrm{kb}$ $S m a I$ fragment containing $t f d A$ of HWl in a broad-host range plasmid vector and introduction of the resulting plasmid into $R$. eutropha JMP228 (pBH501aE) resulted in complementation of the inability of this strain to degrade 2,4-D; JMP228 is a rifampicin-resistant derivative of JMP134 that has been cured of pJP4, and $\mathrm{pBH} 501 \mathrm{aE}$ is a $t f d A^{-}$derivative of pJP4 in which the tfd $A$ gene is disrupted by insertion of a kanamycin resistance gene cassette. Furthermore, the 2,4-D degradation phenotype (or, at least, TfdA activity) of HW1 was shown to be transmissible to JMP228 (pBH501aE), suggesting that the 2,4-D catabolic gene (or genes) is located on a conjugative plasmid like pJP4. Thus, HW1 appeared an appropriate bacterial strain for studies of the genetic origin of the 2,4-D degradation pathway and the assembly of 2,4-D catabolic genes.

Pulsed-field gel electrophoresis revealed that HW1 harbors a large plasmid $(\sim 620 \mathrm{~kb})$, on which $t f d A$ is located. Experimental mating of HW1 and JMP228 strains showed that transconjugants with the ability to degrade 2,4-D were obtained (at a frequency of $5 \times 10^{-7}$ ) only with JMP228 (pBH501aE) as the recipient. Hybridization analysis demonstrated that the large plasmid was not maintained in the transconjugants and that the $t f d A$ gene of these cells was located on pBH501aE. Electroporation of the cloned $t f d A$ gene of $\mathrm{HW} 1$ into JMP228 (pBH501aE) also resulted in the generation of transformants with the ability to degrade 2,4-D. Analysis of both transconjugants and transformants confirmed that the $t f d A$ gene was located on the $\mathrm{pBH} 501 \mathrm{aE}$ at the position corresponding to that of $t f d A$ in pJP4. These results suggest that the $\mathrm{HW} 1$ plasmid is conjugatively 
transferred to JMP228 (pBH501aE) and that the $t f d A$ gene of HW1 subsequently undergoes homologous recombination with $\mathrm{pBH} 501 \mathrm{aE}$. Furthermore, the presence in a pristine environment of a 2,4-D-degrading bacterium that harbors the canonical $t f d A$ gene on a transmissible plasmid indicates that $\operatorname{tfd} A$ in soil microorganisms such as HW1 might be the origin of the gene in 2,4-D degraders present in 2,4-D-treated cultivated fields, although the intrinsic function of the gene in untreated environments remains to be determined.

\section{Perspectives}

Although the behavior of PCNB in nature and the effects of residual pesticide on the population dynamics of soil microorganisms require further investigation in different types of fields, our results provide important insight into the microbial degradation of PCNB. Previous studies of the microbial degradation of 2,4-D have resulted in the identification of various 2,4-D degraders and their catabolic genes. Our strategy of characterizing 2,4-D-degrading microorganisms isolated from pristine environments may provide a rare opportunity to define recent events in the molecular evolution of new metabolic pathways for pesticide degradation. Furthermore, progress in our understanding both of the mechanisms of microbial degradation of PCNB in soil environments as well as of the molecular evolution of 2,4-D metabolic pathways should eventually lead to the development of bioremediation protocols for the treatment of soil or groundwater that is contaminated with these chlorinated aromatic compounds. 